\title{
The use of high rate algal ponds for the treatment of marine effluent from a recirculating fish rearing system
}

\author{
P Pagand ${ }^{1}$, J-P Blancheton ${ }^{2}$, J Lemoalle $^{3} \&$ C Casellas ${ }^{1,{ }^{*}}$
}

\author{
1 Département Sciences de l'Environnement et Santé Publique, Université de Montpellier I, UMR 5556, Faculté \\ de Pharmacie, 15, Av. Ch. Flahault, 34060 Montpellier, France \\ 2 IFREMER, Chemin de Maguelone, 34250 Palavas-les-Flots, France \\ 3 GAMET/IRD, 361, rue J-F. Breton, 34033 Montpellier Cedex 1, France
}

*: Corresponding author : Tel: (33) 4675480 64, Fax: (33) 4670459 33, E-mail: casellas@univ-montp2.fr

\begin{abstract}
:
A high rate algal pond (HRAP) system was used to treat effluent from a recirculating sea water aquaculture system in southern France. Dicentrarchus labrax L. were farmed at a high density, with effluents containing an average of $10 \mathrm{mg}$ L1 dissolved inorganic nitrogen (DIN) and $1.3 \mathrm{mg}$ L1 reactive phosphorus (RP). On a yearly basis, the algal pond removed $59 \%$ of the dissolved nitrogen and $56 \%$ of the phosphorus input, which was converted into $3.3 \mathrm{~kg} \mathrm{DW} \mathrm{m2} \mathrm{algae.} \mathrm{Green} \mathrm{macroalgae} \mathrm{were}$ dominant throughout the year and the algal biomass mirrored the seasonal changes in daily irradiance and temperature. This first year study supports the possibility of treating marine aquaculture wastes using HPAPs, although conditions will have to be found to mitigate the strong influence of climate on the algal community during winter. During the more temperate season, only $150 \mathrm{~m} 2$ of treatment ponds would be necessary to remove the nutrients produced by 1 ton of fish. Treated water was characterized by a high $\mathrm{pH}$, elevated levels of dissolved oxygen (midday value) and low concentrations of nutrients and suspended solids. The absence of toxic phytoplankton meant that the water could be recycled through the farm tanks.
\end{abstract}




\section{Introduction}

One of the main drawbacks of fish culture lies in the waste derived from fish feed and its metabolic end products (Krom \& Neori 1989). The main products are uneaten food, faeces and excreted dissolved inorganic nutrients which are transported in the water at various concentrations (Dosdat 1992a, 1992b). In highly flushed systems, such as cage culture in the open sea, Norwegian fjords or in raceways, waste output is distributed at low concentrations in a large volume (Aure \& Stigebrandt 1990). However, in semi-closed or recirculating systems, much less water is used and there is a high concentration of waste products, making treatment techniques mandatory. The use of recirculating water systems is one approach used to limit the impact of aquaculture on the aquatic environment. Although the total quantity of nutrients released is similar in open and recirculating systems, the small volumes of concentrated effluents that are produced should be easier to deal with, although proper technical and economical solutions have to be implemented.

The use of algae for the treatment of marine aquaculture wastes has been proposed by a number of authors (Villon 1989; Vandermeulen \& Gordin 1990; Lefebvre, Hussenot \& Brossard 1996). Harlin, Thorne-Miller \& Thursby (1978) have already set up a closed low density fish farm including a treatment unit containing Ulva lactuca or Gracilaria verrucosa. A recent study by Neori, Krom, Ellner, Boyd, Popper, Rabinovitch, Davison, Dvir, Zuber, Ucko, Angel, \& Gordin (1996) showed the capacity of Ulva sp. ponds to significantly reduce the concentration of dissolved nitrogen in effluents from a low density $\left(20 \mathrm{~kg} \cdot \mathrm{m}^{-3}\right)$ seabream farm pond at Eilat (Aqaba) in Israël. But, to our knowledge, the high rate algal ponds (HRAP) technique described by Oswald (1988), where mechanically induced turbulence enhances algal productivity, has not yet been tested on effluents from high density $\left(100 \mathrm{~kg} \cdot \mathrm{m}^{-3}\right)$ fish farms.

As part of a pilot experiment for intensive farming of D. labrax in a recirculating semi-closed sea water circuit, we have treated part of the effluents in a high rate algal pond. The objective of this study was to test the efficiency of HRAP on highly concentrated effluents over an annual cycle with pronounced seasonal variations. This experiment was carried out on the Mediterranean coast of France.

\section{Materials and methods}

\section{The recirculating rearing system}

The rearing system consisted of two 10 cubic meter tanks connected to a recycling loop through which the water circulated (figure 1). The total volume of the system was $24 \mathrm{~m}^{3}$ and the water flow rate through the loop was set at $30 \mathrm{~m}^{3} \cdot \mathrm{h}^{-1}$. The temperature, dissolved oxygen concentration and photoperiod in the tanks (figure 1 , sub-unit 1 ) were kept constant $\left(22 \pm 1^{\circ} \mathrm{C}, 6 \pm 0,5 \mathrm{mg} \mathrm{O} \mathrm{O}_{2} \cdot \mathrm{L}^{-1}\right.$ and 16 hours light per day, respectively) and fish density was maintained at around $100 \mathrm{~kg} \cdot \mathrm{m}^{-3}$. In the recirculating loop, the largest particles were allowed to sediment in a particle separator (figure 1, sub-unit 2), and the finer particles were retained on a mechanical filter (50 $\mu \mathrm{m}$ mesh; figure 1 , sub-unit 3). Carbon dioxide produced from breathing was partly removed on a counter current air/water column (figure 1, sub-unit 4) before the water entered the pumping tank, where sodium hydroxide (to avoid a drop in the $\mathrm{pH}$ and an excess of dissolved carbon dioxide) and oxygen were added (figure 1, sub-unit 5). Fresh sea water was introduced simultaneously into this tank at a controlled flow rate so that the residence time of water within the whole system was 
close to 1 day. Compared with open systems or raceways used for the same species, where the residence time of water is usually close to 1 hour, the present system may be considered as semi-closed. Wastewater was removed from the pumping tank via an overflow pipe at about the same rate. The filtered and aerated mixture water was pumped into a steriliser (figure 1, sub-unit 7) to prevent bacterial development, and then through a nitrifying biofilter (figure 1, sub-unit 8) which partly transformed residual organic matter into inorganic matter and ammonia into nitrate.

The sludge from the particle separator was discarded separately as almost solid waste. The daily liquid output from the system consisted of small volumes of water that were used to clean the mechanical filter and about $24 \mathrm{~m}^{3}$ that were removed from the pumping tank. HRAP was applied to a fraction of this liquid output to test whether this kind of biological treatment could significantly reduce the nutrient content of the effluent and thus allow a partial reutilization of the water in the rearing system.

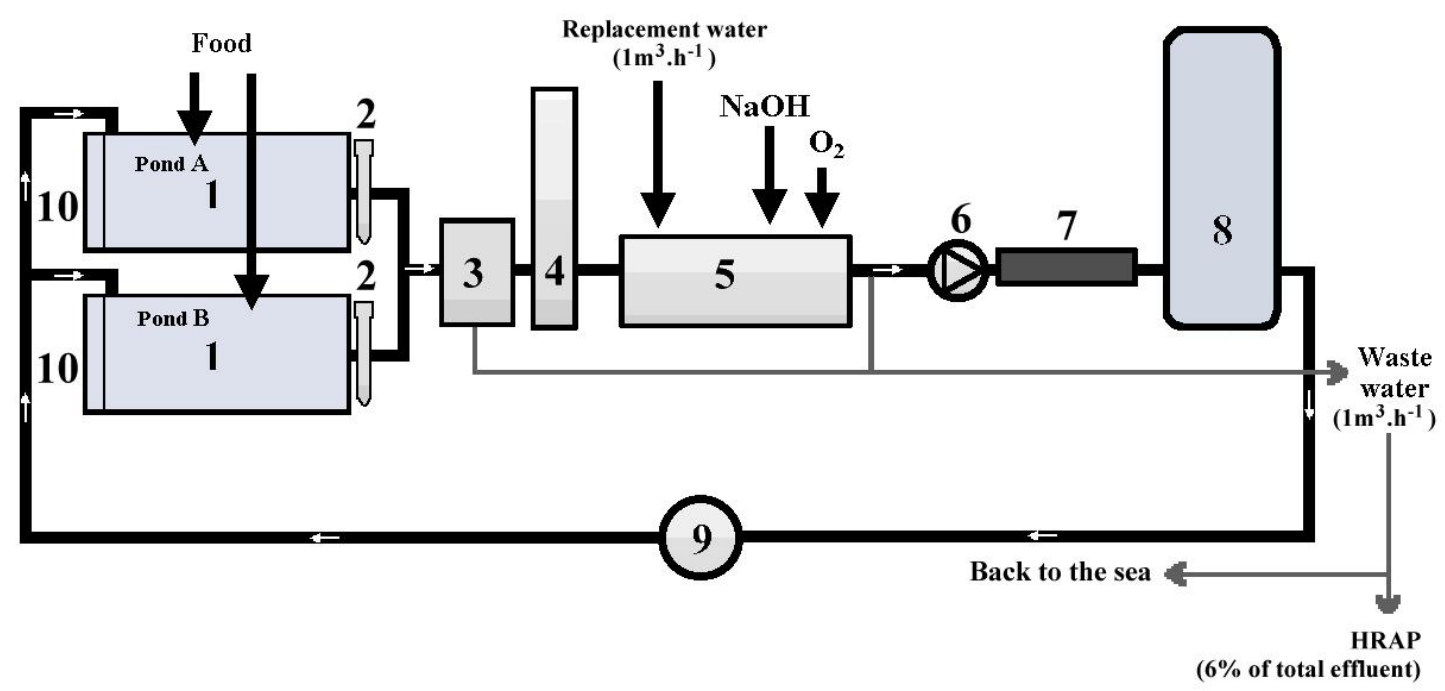

figure 1: Diagram of the recirculating rearing system.

1: farm tank; 2: particle separator; 3: mechanical filter; 4: CO2 stripping system; 5: pumping tank; 6: pumps; 7: UV lights; 8: nitrifying biofilter; 9: heat-cold exchanger; 10: oxygen supply system.

\section{The HRAP treatment unit}

As shown in figure 2, the outdoor oxidation pond was a $0.8 \mathrm{~m}$ wide channel through which water was driven by a paddle wheel. It was fed with $1.5 \mathrm{~m}^{3}$ per day of the liquid effluent mentioned above. The pond had a surface area of $11.8 \mathrm{~m}^{2}$, a depth of $0.5 \mathrm{~m}$ and a volume of $5.9 \mathrm{~m}^{3}$. Water residence time in the HRAP was 3.6 days throughout the entire experiment, from May 1996 to August 1997.

A careful analysis indicated that the mean water velocity induced by the paddle wheel rotation was $15.3 \mathrm{~cm} . \mathrm{s}^{-1}$. It only fell below $10 \mathrm{~cm} . \mathrm{s}^{-1}$ in very limited areas . This movement prevented any significant sedimentation within the basin and ensured an active dispersion and use of the nutrients by the algae. Using a fluorescent dye it was also shown that although the inflow pipe was only a relatively short distance upstream from the outflow pipe, the input composition had no significant effect on the outflow. Output samples can thus be considered as representative of the whole pond.

The pond was first filled with $80 \mu \mathrm{m}$ of filtered seawater before the input valve was opened. The input to the pond consisted of effluent from the farm which had first 
been partly cleared of particles in a settler (residence time of 4 hours). In order to maintain a mean residence time of 3.6 days, the high rate algal pond was fed with 1.1 L.min ${ }^{-1}$ of effluent water, which corresponded to between 3 and $7 \%$ of the total effluent volume released from the semi-closed rearing system.

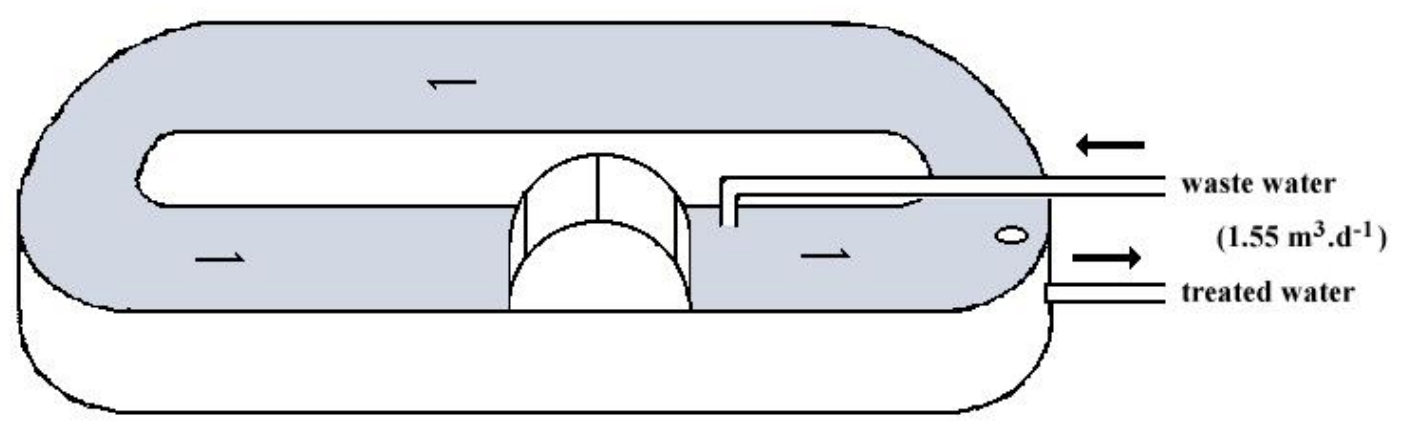

figure 2: The outdoor high rate algal pond unit.

\section{Sampling and analysis}

Daily meteorological data (total irradiance, air temperature, rainfall) were obtained from the nearby Météo-France station at Mauguio. The photosynthetically active radiation $\left(P A R, E \cdot \mathrm{m}^{-2} \cdot \mathrm{d}^{-1}\right)$, which represents around $48 \%$ of the total irradiance, was converted from J.cm ${ }^{-2}$ to $\mu \mathrm{E} . \mathrm{m}^{-2}$ using a $4.210^{4}$ conversion factor (Kirk 1983).

Sampling was carried out over a 15-month period in both the inlet and outlet of the algal pond, twice a week at midday from May to December 1996 and once a week thereafter. Water temperature $\left(\mathrm{T}_{\text {water, }}{ }^{\circ} \mathrm{C}\right)$, dissolved oxygen (DO, $\left.\mathrm{mg} \mathrm{O}_{2} \cdot \mathrm{L}^{-1}\right)$, $\mathrm{pH}$ and salinity (S, g. $\mathrm{L}^{-1}$ ) were measured in situ with a Hg-thermometer, an YSI probe, a Orion $\mathrm{pH}$-meter and a refractometer respectively. The concentration of total and inorganic suspended solids was determined according to Aminot (1983a) on glassfibre filters after filtering the samples through a $500 \mu \mathrm{m}$ mesh net. The concentration of dissolved inorganic nitrogen (DIN in the form of nitrate, nitrite and ammonium) and dissolved reactive phosphorus (RP) were measured on filtered samples with a Technicon ${ }^{\circledR}$ Autoanalyzer II, as described by Treguer \& Le Corre (1974). The error on all measurements was below $5 \%$.

The total macroalgal biomass exported from the system was collected on a fine mesh net at the basin outlet. Conversion to dry weight was based on $100 \mathrm{~g}$ fresh weight sub-samples which were oven dried for one week at $50^{\circ} \mathrm{C}(1 \mathrm{~g}$ fresh weight $=0.2 \mathrm{~g}$ dry weight). The total chlorophyll-a (uncorrected for phaeopigments) was measured with a spectrophotometer after acetone extraction (Aminot 1983b). The phytoplankton biomass was estimated from the mean percentage of chlorophyll- $a$ in phytoplankton, as observed by Desortová (1981) (1 mg Chlorophyll- $a=200$ mg dry weight).

\section{Results}

The climatic conditions on the experimental site were mild, with mean monthly temperatures and irradiance as shown in Table 1 . The strongest irradiance $\left(60 \mathrm{E} \cdot \mathrm{m}^{-2} \cdot \mathrm{d}^{-1}\right)$ and the highest temperatures $\left(24^{\circ} \mathrm{C}\right)$ were observed in June and July respectively, and the lower values in December and January $\left(9 \mathrm{E} \cdot \mathrm{m}^{-2} \cdot \mathrm{d}^{-1}\right.$ and $7^{\circ} \mathrm{C}$ respectively). This reflects the fact that the French western Mediterranean coast has 
one of the highest annual levels of irradiance in France , but experiences seasonal variations due to its $43^{\circ} 30$ North latitude.

Some of the physical characteristics therefore displayed strong seasonality: the variations in water temperature of the outdoor oxidation basin closely paralleled the mean air temperature (table 1). The salinity of the farm effluent ranged from 21 to $43 \mathrm{~g} . \mathrm{L}^{-1}$, mostly as a result of evaporation in summer and of dilution of the coastal sea water during heavy winter rainfall. A mean difference of $2.2 \mathrm{~g} . \mathrm{L}^{-1}$ between input and output pond salinity reflected a daily evaporation of about 1 to $3 \%$ of the pond volume, resulting from an evaporation rate ranging from 5 to $15 \mathrm{~mm} \cdot \mathrm{d}^{-1}$. This loss of water was significantly higher than water input from direct rainfall, which amounted to only 1 to $5 \mathrm{~mm} \cdot \mathrm{d}^{-1}$ (table 1 ).

During the course of the experiment both the $\mathrm{pH}$ and the DO concentration of the input water were lower than in natural sea water and remained stable at around $7.6 \pm 0.1$ and $2.8 \pm 1.0 \mathrm{mg} \mathrm{O}_{2} \cdot \mathrm{L}^{-1}$ respectively. The $\mathrm{pH}$ measured in the pond at around midday generally rose to above 9.0, except during the cold season (December to February). The DO concentration in the pond water (midday values) was always above saturation and reached 10 to $15 \mathrm{mg} \mathrm{O} \cdot \mathrm{L}^{-1}$, although extreme values were avoided due to the paddle wheel effect which tended to maintain the concentration closer to equilibrium. Probably for the same reason, early-morning oxygen concentrations were always above $5 \mathrm{mg} \cdot \mathrm{L}^{-1}$.

In the input water, the concentration of fine suspended solids (suspended solids between 1.2 and $500 \mu \mathrm{m}$ ) varied between 3.5 and $14.5 \mathrm{mg}$. $\mathrm{L}^{-1}$, with an average of 8.0 mg. $\mathrm{L}^{-1}$. This value was significantly higher in the pond effluent $\left(16.1 \mathrm{mg} . \mathrm{L}^{-1}\right)$, which contained the microalgal biomass ; the maximum level was reached in May 1997.

The input water contained an average of $1.3 \mathrm{mg} . \mathrm{L}^{-1}$ reactive phosphorus and $10.2 \mathrm{mg} . \mathrm{L}^{-1}$ dissolved inorganic nitrogen, of which more than $80 \%$ was in the form of nitrate. Output concentrations were significantly lower, and showed strong seasonal variations (figure 3 and 4). If inputs and outputs are computed as monthly fluxes, the reduction in nitrogen varied by over $90 \%$ in summer and by $30 \%$ in winter and that of phosphorus by between 70 and $0 \%$ for the same seasons. The very low values of both the biomass and removal efficiencies in January and February 1997 can be attributed to a particularly cold period (the water temperature occasionally fell below zero) which was detrimental to the algae.

The difference between monthly input and output fluxes of dissolved nutrients may be attributed to algal production, part of which is exported from the pond (figure 5). The exported biomass, which was directly related to the biomass concentration within the pond, fluctuated with the seasons and had a marked low point during winter.

Macroalgae were dominant all year long and the phytoplankton biomass was relatively low, except at the very beginning of the experiment and during Nitzschia sp. and Euglena sp. blooms in May 1997. The data presented below refer to the period from August 1996 to July 1997, after three months of colonisation. In one year, $39 \mathrm{~kg}$ of algal dry weight were exported from the pond. The macroalgae species were usually free floating and fixed ulvoids (Ulva sp., Enteromorpha sp.) but during the cold season Ectocarpus sp. was observed on fragments of ulvoids. Diatomophycae and Euglenophycae were the main species of phytoplankton represented. No toxic phytoplankton blooms were observed during the experiment. 


\begin{tabular}{|c|c|c|c|c|c|}
\hline Month & $\begin{array}{c}\text { PAR } \\
\left(\text { E. } \mathbf{m}^{-2} \cdot d^{-1}\right)\end{array}$ & $\begin{array}{c}\text { Air temperature } \\
\left({ }^{\circ} \mathrm{C}\right)\end{array}$ & $\begin{array}{l}\text { Water temperature } \\
\left({ }^{\circ} \mathrm{C}\right)\end{array}$ & $\begin{array}{l}\text { Inlet salinity } \\
\left.\text { (g.L }{ }^{-1}\right)\end{array}$ & $\begin{array}{c}\text { Rainfall } \\
\left(\text { (mm.month }^{-1}\right)\end{array}$ \\
\hline May 96 & 52,0 & 16,8 & 19,0 & 37 & 26 \\
\hline Jun 96 & 59,3 & 22,2 & 26,5 & 40 & 27 \\
\hline Jul 96 & 54,6 & 23,7 & 25,1 & 36 & 29 \\
\hline Aug 96 & 47,0 & 22,6 & 23,9 & 36 & 63 \\
\hline Sep 96 & 37,5 & 17,9 & 18,5 & 39 & 64 \\
\hline Oct 96 & 23,9 & 15,4 & 16,0 & 37 & 52 \\
\hline Nov 96 & 14,3 & 10,6 & 11,5 & 34 & 92 \\
\hline Dec 96 & 8,6 & 8,4 & 10,3 & 31 & 165 \\
\hline Jan 97 & 11,3 & 7,0 & 8,2 & 28 & 134 \\
\hline Fev 97 & 22,1 & 9,6 & 10,2 & 33 & 3 \\
\hline Mar 97 & 40,2 & 13,1 & 15,5 & 37 & 0 \\
\hline Apr 97 & 49,8 & 14,1 & 16,5 & 39 & 12 \\
\hline May 97 & 47,9 & 17,6 & 18,6 & 36 & 27 \\
\hline Jun 97 & 45,8 & 20,2 & 21,6 & 35 & 129 \\
\hline Jul 97 & 56,1 & 23,1 & 24,3 & 38 & 16 \\
\hline
\end{tabular}

Table 1: Monthly environmental data at the experimental site (from Météo France and our measurements). 


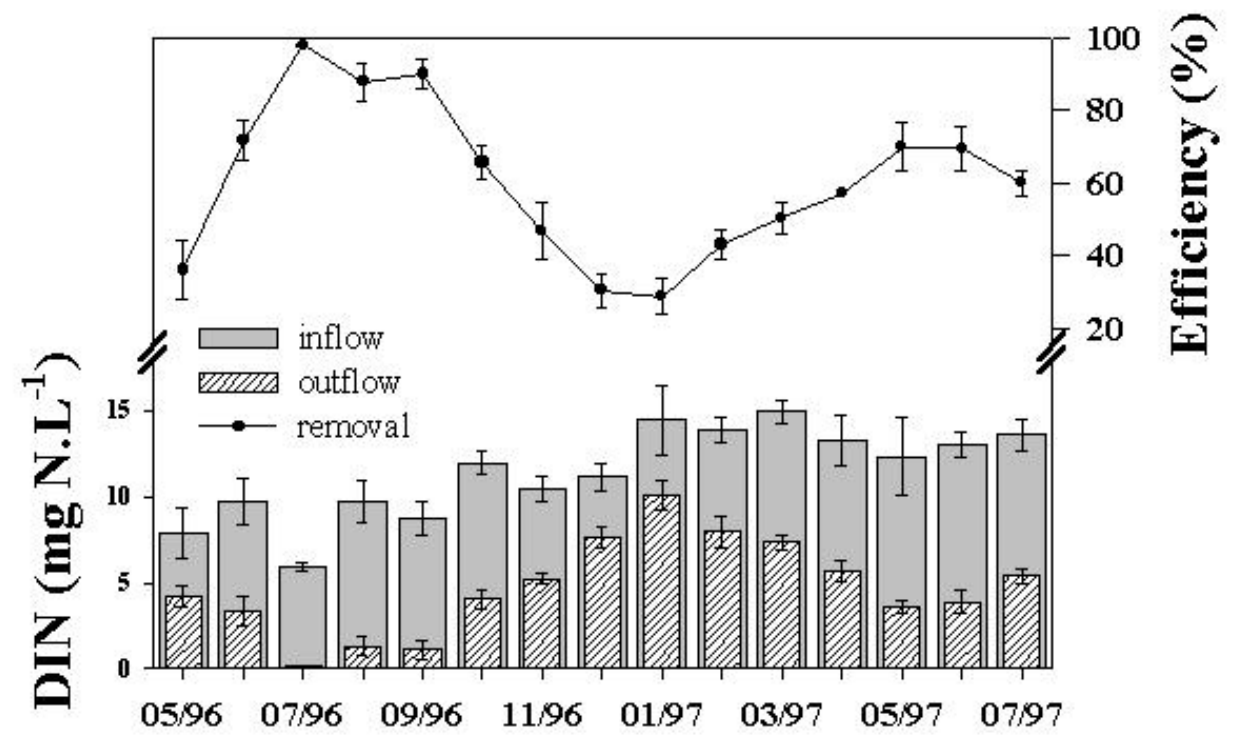

figure 3: Monthly (mean \pm SE) Dissolved Inorganic Nitrogen (DIN) concentration and removal efficiency in the treatment pond.

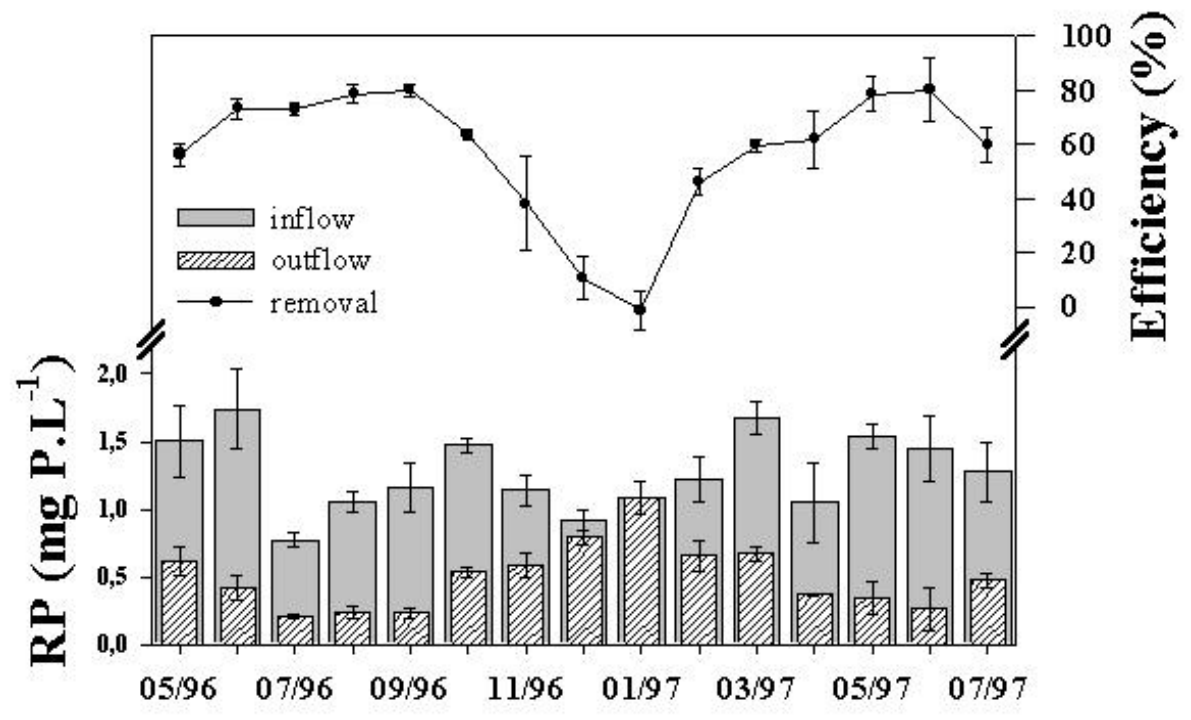

figure 4: Monthly (mean \pm SE) Reactive Phosphorus (RP) concentration and removal efficiency in the treatment pond. 


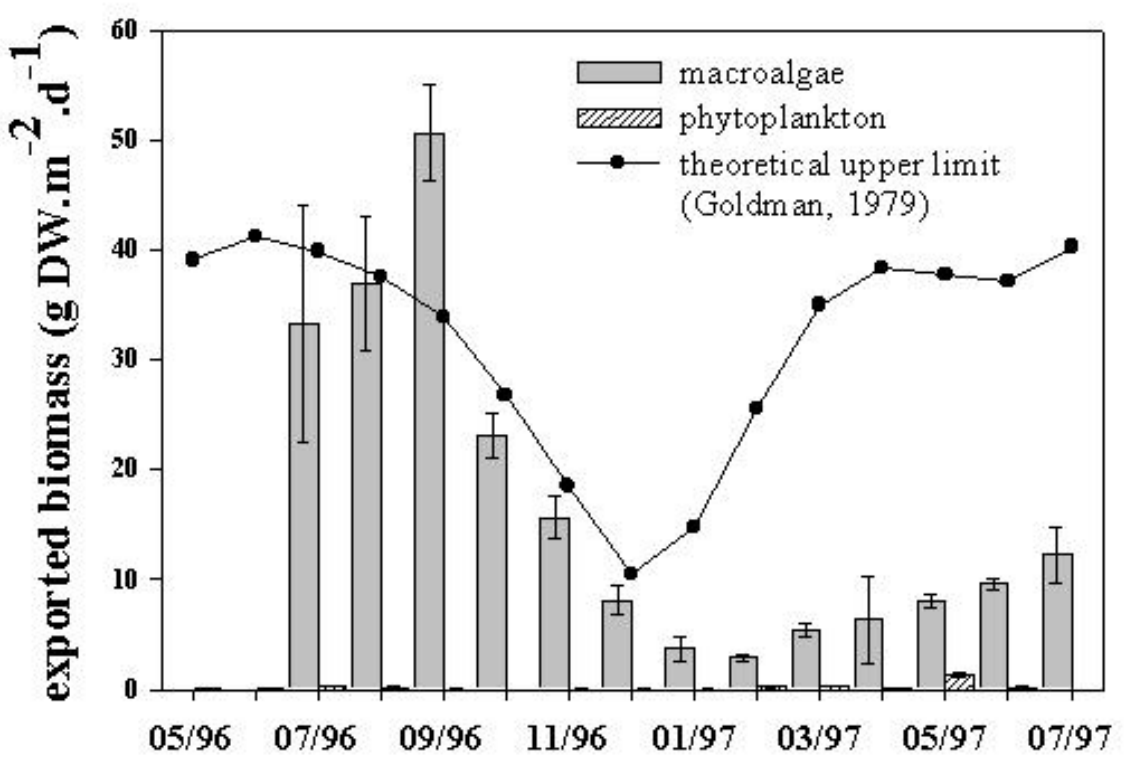

figure 5: Seasonal variations of the total exported algal biomass and of its theoretical upper limit (see text).

\section{Discussion}

Green macroalgae are prone to develop in highly eutrophic or nitrogen enriched marine bays and coastal lagoons where they outcompete microalgae. But the development of the few species occurring naturally is closely dependent on temperature and/or irradiance, as shown by the fact that they almost disappear during winter. In a high rate algal pond, algal activity (oxygen production, CO2 and nutrient uptake for algal development) is also highly dependent on the environmental conditions. Temperature, irradiance and day length are more suitable for algal development during the summer.

Although microalgae usually develop in fresh water treatment ponds, (Goldman, Tenore, Ryther \& Corwin 1974; Oswald 1988; Picot, El Halouani, Casellas, Moersidik \& Bontoux 1991; Nurdogan \& Oswald 1995), macroalgae dominate in shallow enriched brackish or marine waters (Sfriso, Pavoni \& Marcomini 1989; Le Pape \& Menesguen 1993). Smith, Horn, \& Bloesch (1988) assign this drop in phytoplankton biomass to the competition for inorganic nitrogen by Ulva spp. and Enteromorpha spp. These ubiquitous species grow over a large range of temperatures, irradiance and salinity, but are mostly restricted to the summer period in our region (Arnold \& Murray 1980; Duke, Lapointe \& Ramus 1986; Henley 1992; Floreto, Hirata, Ando \& Yamasaki 1993).

The development of macroalgae instead of phytoplankton may be considered beneficial for two reasons. The first is that algal material can be removed more easily. The second concerns the potentially higher productivity that could be obtained if irradiance distribution within the water column, turbulence, temperature, nutrient concentration and input could be properly determined and controlled 
(Goldman 1979; Wetzel 1983). The objective here was to determine these conditions in order to maximize nutrient removal.

In our experiment, higher than usual input concentrations were used, with annual means from August 96 to July 97 of $12.5 \mathrm{mg} \mathrm{N} . \mathrm{L}^{-1}$ and $1.3 \mathrm{mg}$ P.L $\mathrm{L}^{-1}$. The removal rate for dissolved inorganic nitrogen varied between 30 and $88 \%$, with an annual mean of 59\%. Phosphorus removal efficiency varied from 0 to $82 \%$, with a mean of $56 \%$. Similar values for removal efficiency have been published for algal ponds fed with effluents from open circuit marine aquaculture systems, with a much lower N input concentration (Vandermeulen \& Gordin 1990; Cohen \& Neori 1991; Jiménez del Río, Ramazanov \& García-Reina 1996).

In terms of surface area, the mean DIN input varied from 0.8 to $1.9 \mathrm{~g} \mathrm{~N} . \mathrm{m}^{-2} . \mathrm{d}^{-}$ ${ }^{1}$ with an annual mean of around $1.6 \mathrm{~g} \mathrm{~N} \cdot \mathrm{m}^{-2} \cdot \mathrm{d}^{-1}$. Obviously, the removal efficiency will decrease when the nutrient input is in excess of the potential assimilation rate per unit area. The surface area of the treatment pond (or the input flow rate) should be adapted to the variations in the potential maximum as a function of irradiance and temperature.

In our pond, turbulence prevented the growth of large specimens of macroalgae, and pieces of about $10 \mathrm{~cm}^{2}$ were distributed throughout the water column. Photosynthesis by this algal material could thus be considered as similar to that of phytoplankton and was compared with the upper limits of yields attainable in outdoor mass cultures such as those proposed by Goldman (1979):

$$
\mathrm{P}_{\max }=0.28 \mathrm{I}_{\mathrm{s}}\left(\operatorname{Ln}\left(0.45 \mathrm{I}_{0} / \mathrm{I}_{\mathrm{s}}\right)+1\right)
$$

where $P_{\max }$ is in $g$ dry weight.m ${ }^{-2} \cdot \mathrm{d}^{-1}, \mathrm{I}_{\mathrm{s}}$ is the saturation irradiance, in cal.cm $\mathrm{cm}^{-2} \cdot \mathrm{d}^{-1}$ (PAR) and $\mathrm{I}_{0}$, the irradiance on the basin surface in cal.cm ${ }^{-2} \cdot \mathrm{d}^{-1}$ (PAR). With an average $I_{s}$ value of $0.04 \mathrm{cal}^{-\mathrm{cm}^{-2}} \cdot \mathrm{min}^{-1}$, the upper limit of production in our region would range from $10 \mathrm{~g} \cdot \mathrm{m}^{-2} \cdot \mathrm{d}^{-1}$ in December to $40 \mathrm{~g} \cdot \mathrm{m}^{-2} \cdot \mathrm{d}^{-1}$ during June and July (figure 5). The observed seasonal variations in $\mathrm{N}$ and $\mathrm{P}$ assimilation per unit area, as well as those of total dry weight production, are closely parallel to the variations of the theoretical upper limit (figure 6).

Over one year (August 96-July 97) $3.3 \mathrm{~kg} \cdot \mathrm{m}^{-2}$ of algal dry weight (5\% of which was phytoplankton) were exported from our $11.8 \mathrm{~m}^{2}$ treatment pond, trapping $0.34 \mathrm{~kg}$ DIN and $0.034 \mathrm{~kg}$ of reactive dissolved phosphorus per square meter.

The overall photosynthetic activity resulted in daytime $\mathrm{pH}$ values and oxygen concentrations which were in accordance with a possible re-injection (preferably during day time) into the fish tanks. The final nutrient concentrations of the water treated in the high rate algal pond also seemed low enough to be reused in the farm and thus reduce water consumption. 


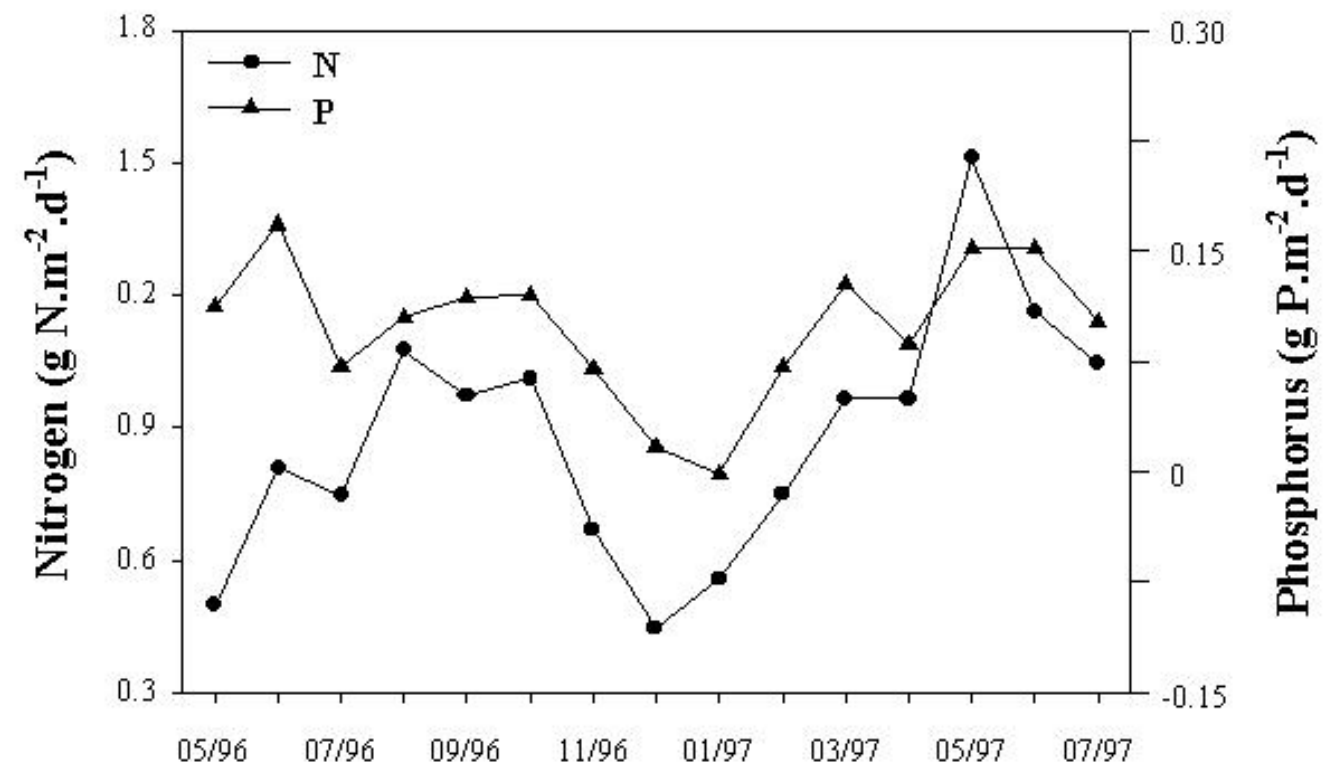

figure 6: Seasonal variations of dissolved $\mathrm{N}$ and $\mathrm{P}$ assimilated per unit area (g.m-2.d-1) in the HRAP pond.

\section{Conclusion}

This study demonstrated that the high rate algal pond technique may be used for the treatment of marine aquaculture effluents from semi-closed circuits characterised by high nutrient, and specifically nitrate, concentrations. As in the nearby coastal lagoons, macroalgae were dominant. One of the main advantages of a high rate algal pond containing mainly macroalgae is the ease with which the algal biomass can be removed from the treated water by mechanical means.

On average, $60 \%$ of dissolved inorganic nitrogen and dissolved reactive phosphorus were removed, although this efficiency varied strongly with the seasons, from $98 \%$ in July to less than $18 \%$ in December for nitrogen. More experiments are thus needed to improve treatment efficiency during winter. If the input rates can be considered stable, the use of a combination of a standard water depth and water residence time did not allow for the conditions in the HRAP pond to be optimized: the strong variations in temperature and irradiance probably resulted in a variable photosynthetic yield of the algae. A longer residence time and a shallower optical depth in the basin might partly compensate for the reduced $I_{S}$ and irradiance during winter on condition that the photosynthetic optimal rate (of the mixed micro- and macraoalgal community) is not too severely depressed by the low temperatures. However, the local climatic conditions in winter, and specifically the low irradiance, set an upper limit to biomass production (around $15 \mathrm{~g} \mathrm{DW} \cdot \mathrm{m}^{-2} \mathrm{~d}^{-1}$ ) and thus to the potential removal of dissolved $\mathrm{N}$ and $\mathrm{P}\left(0,15\right.$ and $\left.0.015 \mathrm{~g} \cdot \mathrm{m}^{-2} \mathrm{~d}^{-1}\right)$. 


\section{Acknowledgement}

We are grateful to Mrs J. Melard for all nutrients analyses performed in this study.

\section{References}

Aminot A. (1983a) Mesure des matières en suspensions. In: Manuel des analyses physico-chimiques en milieu marin (Aminot A. and Chaussepied), pp. 169-175. CNEXO, BNDO/ Documentation, Brest.

Aminot A. (1983b) Dosage de la chlorophylle et des phéopigments par spectrophotomètrie In: Manuel des analyses physico-chimiques en milieu marin (Aminot A. and Chaussepied), pp. 177-192. CNEXO, BNDO/ Documentation, Brest.

Arnold K. E. and Murray S. N. (1980) Relationships between irradiance and photosynthesis for marine benthic green algae (Chlorophyta) of differing morphologies. Journal of Experimental Marine Biology and Ecology 43, 183192

Aure J. and Stigebrandt A. (1990) Quantitative estimates of the eutrophication effects of fish farming on fjords. Aquaculture 90, 135-156.

Cohen I. and Neori A. (1991) Ulva lactuca biofilters for marine fishpond effluents I. Ammonia uptake kinetics and nitrogen content. Botanica Marina 34, 475-482.

Desortová B. (1981) Relationship between Chlorophyll-a concentration and phytoplankton biomass in several reservoirs in Czechoslovakia. International Revue Ges. Hydrobiology. 66, 153-169.

Dosdat A. (1992a) L’excretion chez les poissons téléostéens I. Azote. La pisciculture française 108, 25-37.

Dosdat A. (1992b) L'excretion chez les poissons téléostéens II. Le Phosphore. La pisciculture française 109, 18-28.

Duke C.S., Lapointe B.E. and Ramus J. (1986) Effects of light on growth, RuBPCase activty and chemical composition of Ulva species (Chlorophyta). Journal of Phycology 22 362-370.

Floreto E.A.T., Hirata H., Ando S. and Yamasaki S. (1993) Effects of temperature, light intensity, salinity and source of nitrogen on the growth, total lipid and fatty acid composition of Ulva pertusa Kjellman (Chlorophyta). Marine Biology 36, 149-158.

Goldman J. C., (1979) Outdoor algal mass cultures. II. Photosynthetic yield limitations. Water Research 13, 119-136.

Goldman J. C., Tenore K. R., Ryther J. H. and Corwin N. (1974) Inorganic nitrogen removal in a combined tertiary treatment-marine aquaculture system. Removal efficiencies. Water Research 8, 45-54.

Harlin M. M., Thorne-Miller B. and Thursby G. B. (1978) Ammonium uptake by Gracilaria sp. (Florideophyceae) and Ulva lactuca (Chlorophyceae) in closed system fish culture. Proceedings. of the Inernational Seaweed Symposium pp. 285-192.

Henley W.J. (1992) Growth and photosynthesis of Ulva rotundata (Chlorophyta) as a function of temperature and square wave irradiance in indoor culture. Journal of Phycology 28, 625-634. 
Jiménez del Río M., Ramazanov Z. and García-Reina G. (1996) Ulva rigida (Ulvales, Chlorophyta) tank culture as biofilters for dissolved inorganic nitrogen from fishpond effluents. Hydrobiologia 326/327, 61-66.

Kirk J. T. O. (1983) Light and photosynthesis in aquatic ecosystems. Cambridge Univ. Press, Cambridge. 401 pp.

Krom M. D. and Neori A. (1989) A total nutrient budget for an experimental intensive fishpond with circularly moving seawater. Aquaculture 83, 345-358.

Lefebvre S., Hussenot J. and Brossard N. (1996) Water treatment of land-based fish farm effluents by outdoor culture of marine diatom. Journal of Applied Phycology 8, 193-200.

Le Pape, O. and Menesguen, A. (1993) Etude par simulation de la competition microphytes-macrophytes pelagiques en zone cotiere. Journal de Recherches Oceanographiques, 19, 137-143.

Neori, A., Krom, M. D., Ellner, S. P., Boyd, C. E., Popper, D., Rabinovitch, R., Davison, P. J., Dvir, O., Zuber, D., Ucko, M., Angel, D. and Gordin, H. (1996) Seaweed biofilters as regulators of water quality in integrated fish-seaweed culture units. Aquaculture 141, 183-199.

Nurdogan Y. and Oswald W.J., (1995). Enhanced nutrient removal in high-rate ponds. Water Sciences and Technology 31: 33-43.

Oswald W. J. (1988) Large-scale algal culture systems (engineering aspects). In: Micro-algal biotechnology (Borowitzka M. A. and Borowitzka L. J.), pp. 357394. Cambridge University Press.

Picot B., El Halouani H., Casellas C., Moersidik S. and Bontoux J. (1991) Nutrient removal by high rate pond system in a mediterranean climate (France Water Sciences and Technology 23, 1535-1541.

Sfriso A., Pavoni B. and Marcomini A. (1989) Macroalgae and phytoplankton standing crops in the central Venice lagoon : primary production and nutrient balance. Sciences Total Environment 80, 139-159.

Smith D.H., Horn, A.J. and Bloesch, J. (1988). Experimental measurement of resource competition between planktonic microalgae and macroalgae (seaweeds) in mesocosms simulating the San Francisco bay-estuary, California. Hydrobiologia, 159: 259-269.

Treguer P. and Le Corre P. 1974. Manuel d'analyse des sels nutritifs dans l'eau de mer. Utilisation de l'autoanalyseur II, Technicon ${ }^{\circledR}$, Université de Bretagne Occidentale (Publisher), Brest, France. 110 p.

Vandermeulen H. and Gordin H. (1990) Ammonium uptake using Ulva (Chlorophyta) in intensive fishpond systems : mass culture and treatment of effluent. Journal of Applied Phycology 2, 363-374.

Villon N., Phelepp C. and Martin Y. (1989). Traitement et valorisation des eaux usées de bassins d'élevage de poissons marins: production de plancton et utilisation en élevages larvaires de loups ou de daurade. Vie Marine, 10, 39-50.

Wetzel R. G. 1983 Limnology. Saunders College Publishing, Fort Worth, USA, 767p. 